\title{
An Exploration into the Reveries of Rousseau
}

\author{
Samira Ahansaz (Corresponding author) \\ Faculty of Persian Literature and Foreign Languages, Tabriz University \\ 33, 3rd lane, Alley n. 5, Ghadir Street, Salmas, Iran \\ E-mail: samiraahansaz@yahoo.fr \\ Mahdi Afkhaminia \\ Faculty of Persian Literature and Foreign Languages, Tabriz University \\ The faculty of Persian literature and foreign languages, Tabriz University, Tabriz, Iran \\ E-mail: afkhaminia@yahoo.fr \\ Mustafa Ahansaz \\ Faculty of Persian Literature and Foreign Languages, Tabriz University \\ 33, 3rd lane, Alley n. 5, Ghadir Street, Salmas, Iran \\ E-mail: mustafa_ahansaz@yahoo.com
}

Received: 18-08- 2014

Published: 01-05- 2015
Accepted: 25-11- 2014

doi:10.7575/aiac.ijalel.v.4n.3p.9
Advance Access Published: December 2014

URL: http://dx.doi.org/10.7575/aiac.ijalel.v.4n.3p.9

\begin{abstract}
From Antiquity to the Enlightenment, several biographical writings from Parallel Lives of Plutarch to the Memoirs of Saint-Simon were practiced. However, the eighteenth century saw the first emergence of the autobiography of introspection in the works of Rousseau. This new literary creation, far from being a simple description of memories, contained the analytical study of Rousseau's psychological evolution. Following the tempestuous years of composing the Confessions and the Dialogues, a period of quietude and interior consolation began with the Reveries. In this paper, through examining this final stage of Rousseau's self-analysis, we attempt to procure the answer to the mental problems of modern man; the notions of solitude and falsehood which have been a tragedy for the man of today are herald of «Joie de vivre» in the Reveries. For this end, we examine the analysis carried out by some contemporary authors and critics while having Rousseau's perspective in mind.
\end{abstract}

Keywords: Jean-Jacques Rousseau, definitive solitude, falsehood, self-sufficiency, golden age.

\section{Introduction}

After long period domination of classical dogmatism and following the claims of Encyclopedia against the superstition of the ancients, a new era of prosperity walked into the eighteenth century: the transformation of aesthetics art into the art that expresses inner world of the author. Jean-Jacques Rousseau as a revolutionary philosopher is the first who takes this opportunity to free himself from the never-ending debates and constant quarrels with his contemporaries. The new ideas and theoretical assumptions he puts forward, indicates the freedom he lets into his thought. Anthropology, politics, pedagogy, religion and romance owe a great deal to the "[philosopher] of happy people" (Eigeldinger, 1962, p. 137). We can also view the modern psychology through his latest works which justify the innocent 'self' by attributing the root of any evil to society. In addition, these works accepted new colors in different genres: the Confessions is the precursor in the autobiographical genre; Dialogues takes place in the timeline of critical controversy, and the Reveries that unfolds in clear poetic prose.

Contrary to the Confessions which was considered as a noticeable work from the very beginning, the Reveries remained more or less obscure during the 18th and 19th century. Nevertheless, we can put our finger on some translations of the Reveries among which the translation of the Sixth Promenade by Francis Walker (1828) is of paramount importance.

Since the 20st century, however, the number of works on the Reveries of Rousseau has grown considerably. For instance, Philippe Lefebvre (1978) attempts to decode the religious aspects of the language of the Reveries; Marcel Vérani (1979) is concerned with the political aspect of this work; Jean-François Perrin (1997), among his works on the Reveries, particularly analyzes the theoretical dimension of falsehood in the Forth Promenade; and Ernst Cassirer in the Problem, Jean-Jacques Rousseau demonstrates the thorough unity of the works of Rousseau despite their contradictory appearance.

In the propitious condition of the $18^{\text {th }}$ century, Rousseau finds opportunity to proclaim a new form of «I» in the literary work which takes over from the condemned «I» of classics. He links closely the themes of reverie, the acclaim of human passion, regret at fleeing time, the reminiscence of the joyful past and the creation of the nirvana to an attempt to justify an exalted «I» who has been cut off from the world. Indeed, since the condemnation of Emile, Rousseau, who 
was dismayed by his failures in gaining the support of his contemporaries, was in many disputes with most of his friends and these disputes finally led him to the darkness of a lonely world. The act of absolving himself of calumnious imputations of his opponents formed so much of his autobiographical work. But forcing the idea of the innocence in the minds of the public could only exacerbate the hostility of Rousseau's opponents and it consequently led to his complete exclusion from society. However, no one ventured to deny the remarkable influence of this great philosopher in the foundations of the Romantic School. Instead, it is with the advent of Romanticism rhetoric that Rousseau is respected and pursued by supporters of the priority of sensation. His singular work the Reveries of the Solitary Promenader, produced by the plain language charms, vivid descriptions, and the verisimilitude of the story, could best present the principles of Romanticism.

In the Reveries we encounter the memories of a desperate philosopher who has resigned himself to the inevitable and finally resolved to live inside a world different from the lay man's. For him, the «lost paradise» appears always in a mixture of contrasts; it is in predicament and in the shadow that Rousseau seeks the light of heaven; it is in the absolute solitude that he senses the elegance of the «golden age» and finds an interest in a world beyond (Rousseau, 1995). Differently put, the darkness of his life could not be opened to the light unless through an «ecstatic transport» to the Rousseauist utopia. Why trust the treacherous breaths of this world below? Why have hopes on the people who are blind to the truth? It's unwise to consent to the superiority of an abysmal social existence over solitude because this solitude provides the best opportunity to get to know oneself, and gives free rein to the imagination to create an ideal world.

To solve the enigma of Rousseau's inner world we will present an analysis of the process during which the interested polemicist of Dialogues is transformed into the apathetic misanthrope of the Reveries after he witnessed the hostility of human society and hence turned his face toward the idea of Lost Paradise. The philosophy of falsehood incorporated in the Reveries, which is certainly a very important problem for the theorist of the «natural man», will be also considered here in its various aspects.

\section{A final self-reflection}

Written between 1776 and 1778, the Reveries largely recites the events happened in 1765 which had been previously mentioned in the Confessions. Unlike the Confessions where the author tried to justify his mistakes for human race, in the Reveries he doesn't put any effort to conceal them and attempts to indulge himself with mere pleasure. Stern philosopher of the Social Contract, who was alienated from human society and who sought shelter in the serene nature, finds a softer and more sensitive spirit in the Reveries. Any torment and persecution that Rousseau's opponents had afflicted him with brings him peace in the last years of his life. After being dragged to the most woeful and pathetic state, Rousseau has no fear and concern for the obstacles that his enemies can lay in his way:

They could have me their toy by any false lure, and then for evermore torment me with a renewed torment through my failed expectations. But they exhausted their resources beforehand; they deprived themselves of everything by leaving me nothing. [...] They hastened too much to heighten my misery to its pinnacle that any human power, aided by all the wiles of hell, is not able to add anything more to it. [...] worry and fear are the evils from which they delivered me forever (Rousseau, 1965, p. 31).

His opponents also deprived him of hope on the authentic transmission of his ideas and writings to the posterity. The reason for this despair is manifested best in the First Promenade. According to the explanations of Rousseau, people cannot completely ignore the generation that precedes them. Thus, later scholars who followed in their predecessors' footsteps could not put aside the malicious affronts hurled upon the author of Dialogues. The panic that his ideology was ill-informed to the posterity directed Rousseau to write the Reveries of the Solitary Promenader (Rousseau, 1965). In this book, through the reminiscence of some personal experiences, on one hand he seeks to analyze himself, his own personality and his weaknesses as a real psychologist, as was the case in his Confessions, and on other hand to denounce, with the manner of a moralist, the imposture of his generation. However, the beauty of nature depicted with the magical pen of Rousseau softens the arrogant tone of his writing which, though claimed to be written for pleasure, seems to be made in order to win back the lost credit of the author. This multidimensional characteristic of the work rendered it a mixture of reason and sentimentality, reflection and reverie, reminiscence of mistakes and resurrection of the «lost paradise».

As the use of the adverb "so» in the first line of the book shows ("So see me alone in the world" (p. 29)) the Reveries is the ultimate contemplation of Rousseau and includes the conclusion of his work and his life. It's a last self-reflection where the philosopher develops the integral theme of all his autobiographical work, i.e., the theme of solitude (Bornecque, 1988).

\section{Rousseau and the everlasting solitude}

From the beginning of the book it is the title that informs the reader of the extreme solitude in which Rousseau finds himself. The use of the definite article, «the», for «solitary promenader» in the title of the book lucidly shows that the author is a representative example of any tormented man isolated from society (Bochet, 1997). Rousseau, gifted with a sensitive and sincere spirit, could never belong to a society where the rich have a false sense of superiority. The corrupt laws which dominated the society of his time had made any kind of participation in the community of man intolerable to him as he elegantly states in the Reveries:

I've never really been fitting to the civil society where everything is disturbance, obligation, duty, and my independent nature always made me incapable of submission necessary to anyone who wants to live with man. 
When I act freely I'm good and I do good deeds, but as soon as I feel the yoke emanating from whether necessity or man, I become rebellious or rather stubborn, hence I'm nothing (pp. 113-114).

Thus, having been in discord with most of his contemporaries either because of their malice or because of his own extreme sensitivity, he lost all the ties that once chained him to socialites. In addition, apathy of both the literary men and the public to his Dialogues led him to withdraw permanently to seclusion. Rousseau sensed a «universal opposition» that was increasingly rushing into him and which ultimately led him to make fundamental reforms in his life. After being attacked by the Church, parliament and philosophers who were previously his refuge, he began to take a stand against the world at his forty, the age of wisdom (Bornecque, 1988). Hence he made every effort to enrich his inner world, and it was at the time of writing his Reveries that he became determined to ignore entirely his enemies in order to reach the serenity of heart:

I am a hundred times happier in my solitude than I would be if I lived among them. They have taken away all the comforts of society from my heart. These comforts could no longer germinate once again at my age; it is too late. No matter do they do good or evil to me henceforth, all from their side is the same to me, and whatever they do, my contemporaries, they will never mean anything to me (p. 33).

Accordingly, loneliness took a long time to finally solidify within Rousseau. Nevertheless, still living with the hope of being recognized by mankind as a just being and as a humanist, he began "a thousand crazy attempts to pass on [his Dialogues] to posterity" (p. 33). Contrary to what was expected, the opposed society excluded him aggressively and ultimately pushed him to isolate himself from the world and become a loner. Rousseau's strategy for dealing with this obligation included the transformation of the excruciating loneliness to an enviable solitude by returning to the self (Bochet, 1997). According to Marc Bochet (1997), solitude in Rousseau's book is defined in two ways:

\subsection{Imposed solitude}

In the first lines of the Reveries, Rousseau claims that he is prohibited from leading a social life without his own will:

So here I am alone on the earth, having no brother, neighbor, friend, society except myself. The most sociable and loving of human beings is expelled from society by the unanimous concord (p. 29).

At different times, by variety of expressions, he pointed out throughout his book that his absolute solitude was not the result of his own will; it was actually the world that denied him. In fact, the expulsion of Rousseau from human society had several reasons: 1) the first reason was the disease that the body of Rousseau was afflicted by. The decline of bodily strength distinguished him and pulled him away day by the day from the man; 2) vanity, defined by Rousseau as the source of most vices, was another reason which led Rousseau to withdraw from the world; because in the salons and among literary men, he was always subject to praise and compliment of the people who imbued him with vanity. The eradication of this defect required unchaining the ties of friendship and intimacy with his philosopher comrades, because "Vanity [...] languishes and dies for the lack of food in solitude" (Rousseau, 1999, p. 201); 3) finally, his adoption of a particular religion (theism) that would be refuted by the society of Geneva and Paris on one hand, and on the other his growing mistrust toward the atheist philosophers of his time cut him off from everyone and caused him to sink in the obscurity of an irremediable solitude (Bochet, 1997).

These three reasons could undoubtedly create a greater distance between Rousseau and his contemporaries. Nevertheless, the great philosopher has never ceased to explore new ways to console his soul.

\subsection{Loneliness as one approach chosen}

Instead of resisting against the imposed isolation, Rousseau finally resigned to the causes of his loneliness:

At length while sensing all my efforts futile and tormenting myself in vain, I took the only choice that remained to me which was resigning to my fate without surrender to necessity. In this resignation, I found compensation for all my anguish through the tranquility it provides for me and which could not ally with the continuous act of resistance that is painful as much as it is fruitless (Rousseau, 1965, pp. 30-31).

Rousseau contrasts the sumptuous and pernicious civilized city which did not give him the desirable comfort with the pure and austere surrounding countryside. The nature, far from being an object of study or a place to walk around, is the mother around whose arms Rousseau can discover the mystery of existence and purify his "stained imagination" (p. 126). Even when he is away from nature, he prefers the society of imaginary beings where justice and brotherhood prevail to the company of the wicked man. These fictional images created through his active imagination never betray him (Bochet, 1997). Thus, the overwhelming loneliness is converted to absolute independence of human beings and finally to a redeeming loneliness which is predicated solely upon self-love:

Reduced merely to myself, I nourish, it is true, from my own essence which doesn't diminish and I am sufficient for myself (pp. 135-136).

It is in his dreams and during his promenades within the enchanting nature that Rousseau deepens his knowledge about the mystery of his own existence. In truth, for Rousseau the dream involves the pure outpouring of the initial and natural functioning of mind; this is the state where ideas are freely allowed to take their natural trajectory. This way of thinking is well-suited to the free spirit of Jean- Jacques whose great obsession is to return to his original pure nature. His dreamy promenades are not the simple rambling but are metaphysical meditation. It is from this time that the state of the author becomes stabilized forever, and that self-love is considered as a sublime rectitude. In a heart finally assured of its innocence, confession and justification will no more have space. Rousseau replaces the feeling of hatred 
he could have against the human race with apathy; it is the method that will be defined later by Marcel Proust, in In the Research of lost time, as the only way of decadence of others.

\section{Falsehood: major problem at the heart of Rousseau's philosophy}

When Rousseau moves from Dialogues to the Reveries, he changes significantly his expository mode. Unlike Dialogues where we notice the three fundamentals of epistemological issue, i.e. the observed character «J.J.», the theorist «Rousseau», and the conceptual character the «Frenchman», the Reveries depicts just one promenader who plays the roles of all the characters in Dialogues. The life of this solitary promenader is marked by an "ultimate quest for knowledge framed by the search of the happy life" (Perrin, 2011, p. 185). In this book, the self-analysis which is the study of changes in the self transpires through the observation of everyday life (Perrin, 2011).

Aged Rousseau, who senses the approaching steps of death, is determined to evaluate his achievements for the last time. Although the Reveries is not studied mostly as a philosophical work, it contains important ideas in the field of morality. The major issue that Rousseau faces during the writing of his latest literary creation is the question of falsehood. At the time of the Enlightenment, criteria by which the issue of falsehood is treated are rather based on «Christian theology» and the theory of «natural law». These are the areas which certainly belong to Jean -Jacques Rousseau (Perrin, 2011). The atmosphere of Geneva embalmed by the verses of the Bible created the religious bent in little Jean-Jacques. Thus, the widespread view of disapproval which dominates Rousseau and every action that he takes is probably inspired by the God of Christianity who condemns all vicious acts:

If Rousseau imagines a reproving look in a place where nobody cares about his mediocre existence, it's because the idea of an omniscient and just eye is inseparable from the sky of Geneva. [...] Breathing the air of Geneva is breathing the conviction in original sin; it is to feel the danger of wrath presses upon him (Starobinski, 1999, p. 138).

Yet the pressure of the condemning eye does not seem to be quite destructive because, although this look pushed him to restrain his desires, it also took away from him the destructive effects of certain temptations such as "pernicious lies" (Perrin, 2011, p. 208). Indeed, the theological doctrines that prevailed in the French society of the $18^{\text {th }}$ century divided lies into three groups: the first type is called «pernicious lies» which are told with malice, and are worthy of punishment; the second is called "officious lies" (p. 208) that do not harm anyone but, on the contrary are sometimes of benefit to others; and final one involves the lies that tend to please others or entertain people. From another point of view, proponents of «natural law» theory presented natural instinct as the determinant of falsehood and truth. Rousseau more or less had a propensity toward these two perspectives through which he examined the issue of falsehood, while his mind was influenced by the Christian religion on one hand and on the other he was one of the theoreticians of the «natural man».

Owing to the difficulty he suffers while speaking in public, Rousseau has recourse to the art of writing to compensate for his shortcomings through his literary genius. He finds the art of writing a means to restore the unspoken desire of the past in order to alleviate his inmost being, even though he knows he has lost the addressee of his confession. At times these confessions are granted leaves and branches by his imagination which does not let him leave his writing unadorned. In some other occasions, Rousseau muffles the truth in order to save some of his friends from reproach or punishment. In the Fourth Promenade, Rousseau indicates that he has hidden the fault of his comrade, Pleince, who "gave [his] bare head a stroke, so practical that a stronger hand would have blown [his] brain out" (Rousseau, 1965, p. 85). Rousseau states that he does not regard these additions or unspoken matters as the contribution of innocent imagination but disguises (Perrin, 2011).

These transformations in his works are either the result of "false modesty" (Perrin, 2011, p. 212), or "vanity" (p. 212). From time to time, when Rousseau finds in his works an opportunity to show himself as an eloquent speaker, he decides "to use some neutral ornaments [...] to fill a gap caused by [his] memory's failure" (Rousseau, 1995, p. 151). He also has recourse to the "generous lie" (Perrin, 2011, p. 214) and defames himself in order to benefit others and this is how he becomes responsible for serious crimes to protect Ms. D'Holbach :

Here begins the great and noble task I deservedly fulfilled, to expiate my hidden faults and weaknesses through burthening myself with more serious faults, which I was incapable of committing, and that I never committed (Rousseau, 1995, p. 727).

Earlier in Dialogues, Rousseau tried to reveal a falsehood, a conspiracy that he attributed to the anonymous «Messieurs» who are incarnated as the chief creators of this slander. Moreover, he also attributed it to the public as the followers of this plot, and to posterity as the followers ill-informed by these «Messieurs». All the attempts in Dialogues are summarized in the evaluation of the adequacy or inadequacy of the attribution of guilt to «J.J.». This topic which also raises debates between «Rousseau» and «Frenchman» brings them to an equal conclusion: the inconsistency of the evaluation of J.J.'s affaires without the establishment of public trial for the accused. The aim of «Rousseau» in showing all this diligence is summed up in the "denunciation of the arbitrariness of the French justice, expeditious procedures and torture" (Perrin, 2011, p. 122) and "challenging the nature and administration of evidences" (p. 122).

In the Reveries the problem of falsehood and truth is treated with a new perspective. In order to clarify the concept of lying, Rousseau decides to examine first his own existence. For this reason, he recounts the story of his first grave lie against a little girl, an event which was already mentioned in the second book of the Confessions. Working for some time as a servant to the Countess of Vercellis, little Jean-Jacques steals the comb of his mistress. To escape the wrong he has committed, he unjustly accuses a cook called Marion, who then is expelled from the house instead of him. 
Although it has already been explained fully in the Confessions, the main source of this great vice is again represented by the solitary promenader:

This lie was an upshot of the false shame and it was far from an intention of malice towards the one who was the victim, I can swear by the heavens that the moment when this irresistible shame was tearing me apart, I could give my blood with joy to divert the effect merely on myself (Rousseau, 1965, p. 69).

The fact that he becomes known as the thief if he reveals the truth is the main reason for the shame which follows him as an insurmountable problem for his entire life. In addition, Rousseau owned that some outpourings of his memory claimed as pure reality were a number "of things of [his] invention ... [he had] announced as true" (p. 69).

Moreover, Rousseau identifies various types of lie in his Reveries. The first type of lie that Rousseau illustrates in the Fourth Promenade is «harmful lie» or as Perrin (2011) calls it «pernicious lie» which is considered as harmful for others. The second is «innocent lie» that produces no sense of remorse in the heart of the liar. The interest and prejudice are the two principles that Rousseau utilize to distinguish harmful lie from the innocent lie. This distinction will be followed by several problems. Thanks to his famous motto "lie is hiding a truth that one must show" (p. 70), Rousseau steps into new ways and exhibits two main issues: the first is to identify where we must undoubtedly tell the truth: "When and how we should tell the truth to others, since we do not always have to" (pp. 70-71); the second is "whether there are cases in which we can deceive innocently" (p. 71). The main areas on which Rousseau relied in order to gain favorable results are the public interest and the private interest. Taking into account the importance of general profit, Rousseau then defines two categories of truth 1) «the general truth» which is according to him "the most precious of all possessions. Without it man is blind; it is the eyes of wisdom. It is a means through which man learns to behave, to be what he should be, to do what he needs to do, to reach his true end" (p. 71); 2) and «the particular truth» which "is not always good, sometimes it is bad, very often neutral" (p. 71). The general truth must obviously be given the highest priority, since it aims to provide benefit to everyone. Thereafter, by relying on the conscience that is the foundation of all morality of Rousseau, the circumstances to tell the truth or to conceal it are recognized (Perrin, 2011).

Although the distinction between these circumstances is really hard, Rousseau, by using certain criteria, offers satisfactory explanations. Firstly, he argues that the man doesn't have to say all the truths of his life. For any individual, there are secrets that are unique to him. Secondly, he discerns the conditions that determine whether we should say or conceal the truth. In this sense, Rousseau takes advantage of the «natural law» theorists who claim that to lie is to speak against what we think, i.e., against the natural instinct; in other words, if we disguise or distort our thinking when we transmit it to others and present them a misconception, we lie and we deserve to be punished. As a result, Rousseau illustrates that even a lie which brings benefit to others or to oneself cannot be innocent because it is against the justice. So he rejects the innocence of any «officious lie» by considering justice as equivalent to the truth and iniquity as equivalent to the lie (Perrin, 2011):

The so-called officious lies are the true lies, because influencing the benefit of others or of oneself is no less unjust than influencing their detriment. Anyone who lauds or blames the truth lies, since a real person is at risk (p. 77).

We can conclude based on what mentioned above that Rousseau changes his stance on the imaginary beings. Rousseau discusses that the lie which is told to please or entertain others is not against the justice; fables and stories that are derived from the fiction are in this category. The fiction that pushed Jean- Jacques Rousseau to write his New Heloise is one of the examples of innocent lie that through a fabulous story wises us up to the truth and impart us some favorable moral lessons. However, in the case of autobiographical work, fiction finds another meaning. One of the criteria of the autobiographical genre is its orientation towards the approach of individual truth. That is why the first question that haunts the reader of such works is the sincerity and honesty of the author. The author is in fact inflicted by various difficulties including the betrayal of memory which is inevitable in an autobiography. In addition, the issue of dual personality of the human being that roots in the «voluntary» and «involuntary» is another reason for the inaccuracy of the autobiographical work (Perrin, 2011). One example which is extracted from the Emile illustrates this problem:

By meditating on the nature of man, I believe I have discovered two distinct principles, one of which elevated the nature of man to the study of eternal realities, to the love of justice and the moral beauty, and to the regions of intellectual world, contemplation of which is the delight of the wise, and the other one restricted it [the nature of man] to itself, enslaved it in the empire of the senses and in the passions which are the masters of senses, and by means of these passions nature contradicted all that the primary sentiment inspired. [...] I want and I do not want, I feel myself free and slaved at the same time, I see the good, I like it, and I do evil (Rousseau, 1966, p. 362).

It seems the evil that dwells inside man pushes him necessarily toward villainy and wickedness. This reminds us of the doctrine of original sin in Christianity according to which the human nature is weakened and corrupted from birth by the evil. This is another contradiction that we face in Rousseau's outlook, since on another occasion he states that human vice has its genesis in society and not in human nature.

All in all, in Rousseau's autobiographical work the duality of personality emerges from the fiction which can be viewed as the only disguised material used by him. As to the "due truth [...] that concerns the justice" (Rousseau, 1965, p. 72), he is still "as faithful to the truth which condemns him as he is to the truth that honors him, and [...] he never uses it for his own benefit or harming his enemy" (p. 78). Accordingly, the reasons that have led Rousseau to write his Reveries 
can be concluded as "expanding some beautiful and grand truth, fighting some general and pernicious errors, and finally establishing some useful public benefit" (Bornecque, 1988, p. 72).

\section{Rousseau in search of lost paradise}

In the world of reverie, Rousseau aims to reach a state where, by means of forgetting all his passions and all his pains, he can plunge himself into the pure enjoyment of solitary self while thinking and seeing nothing but his own entity. This is indeed the path that Rousseau chose since the condemnation of Emile, when for the first time he felt himself the victim of a heinous plot. Henceforth, he has begun to indulge in dreams. His life is actually divided into «... the one he was living and the one he was dreaming» (p. 36). Dissatisfied with the imperfections of the real world, he has to take refuge in the safe haven and the supreme world of reverie (Bornecque, 1988).

Rousseau first opened his eyes to the imaginary world before getting caught up in the vortex of the real-life adventures. Rousseau thus embodied the idealized objects of his imagination by seeking their archetypes in real objects (Starobinski, 1999). In the real world, instead of seeing things as they are, he never stopped to find connection between material objects and "the figures of the personal fable" (Starobinski, 1999, p. 162). Starobinski (1999) lucidly explains this concept using the example of the beloved woman:

In Sophie D'Holbach, Rousseau believes he finds the epitome of Julie Etanges, the image of whom he builds with the reminiscence of Eleanor de Warrens (and some others), but he does not stop in the past when he actually used to live with "mom", and he goes on to recreate the youth of this woman, the mysterious time of her first loves. Julie is the dreamed figure of adolescent Eleanor. In reverse, Rousseau could not be interested so intensely in Madam de Warrens unless he could find in her the lady of his first romantic reveries, and the fictive features of a mother lost forever (p. 162).

This world of imagination that bestows him a perfect happiness flourishes best during solitary promenades. For Rousseau, the promenade, rather than a physical act, means the walk of fantasy that imbues the promenader with ecstasy by inviting him to the contemplation over universe and the meditation on his own existence. Opposed thoroughly to the philosophy of his time whose foundation is the realism, Rousseau announces his belief in the «golden age» and the «lost paradise» theories. He rejects the idea of Voltaire according to whom belief in «lost paradise» is the consequence of the regret of "good old days" (Eigeldinger, 1962, p. 137). He speaks quite differently about a perfect happiness he is seeking in the past or wants to recapture in the future:

The belief in the golden age ... is an expression of the desire to evade time, to cut loose from history in order to rejoin the consummation of the origins, to envelop the unity of primordial and elementary, to revive the intemporal moment of Genesis [...]. To deny the myth of the golden age is to kill the spirit of the childhood in man, and to destroy all hope for freedom and innocence and all aspirations to rejoin the primitive unity of being in order to find the language of origins (pp. 138-139).

Considering the expertise of the philosophers of his time as a false wisdom, Rousseau criticized them for naively viewing their paradise to be in the present time in which man dies and decays by the hands of destructive time, and loses the innocence of origins. According to him, this ongoing time can never satisfy the desire of a man who aspires to eternity of Genesis, the innocence of childhood and the perfection of the inner world. The earthly paradise of these skeptics, which is akin to the world sought by Rousseau, is a transient euphoria that fades away in a short time; this enjoyment once acquired will be corrupted by "the eruption of evil and falsehood conscience" (p. 139). This instability persuaded him that a golden age viewpoint which has marked his life and his work is an unattainable utopia and that there is no permanent happiness in this world. Rousseau lessons the nostalgia produced by this impossibility through a "mystical union with the serenity of nature" (p. 142). It is especially in the period when he lived in the island of SaintPierre that he felt the sight of nature better. The island is in fact an unconscious force by means of which the author was protected from malice; it is also a territory of which he believed to be the only conqueror (Eigeldinger, 1962). It is an intermediary between him as a lonely sufferer and "a small island of happiness in the ocean of his sufferings" (Bochet, 1997, p. 65).

Thus, despite the obstacles that prevented him from transforming the real world to the ideal world, Rousseau did never cease to recreate his utopia on the earth because he believed that the constant reminiscence of the «golden age» provoked man to save the virtue and innocence of the origin. However, the reconstruction of peaceful time and felicity was troubled by his enemies during the period when he started to change the dominant ideas in society. This is at the time of writing the Reveries that Rousseau reached a total indifference towards his slanderers and was eventually forced to assent to the forfeiture of his dreams. But this time the isolation imposed by his contemporaries was profitable for him:

In all the refinements of their hate my persecutors have omitted one that their animosity made them forget; it was to gradually intensify the effects they would be maintaining and renew my pain constantly through bringing some new attaint upon me every day. [...] But they have exhausted all their resources in advance; they deprived themselves of everything by leaving me nothing. Defamation, depression, derision, and humiliation that they flooded me with are no longer likely to augment but they reduce (Rousseau, 1965, p. 31).

Overwhelming attacks of his enemies had already lost their intensity when Rousseau agreed to endure the yoke of necessity. Detached from any person and any object, he realized that he had to rely on himself. It was the peace and the self-confidence that his enemies brought him by removing from him "inquietude and fear" (p. 31). Thus, it was in his 
inner world that Rousseau eventually tracked down the «golden age» he was seeking which could not be touched and experienced but inwardly (Eigeldinger, 1962).

\section{Conclusion}

The Reveries as the final work of Jean- Jacques Rousseau is like a soliloquy poem that a dignified solitary chants in a hymn to loneliness and in the hope of a delightful happiness. Being unable to overcome the solitude imposed by his contemporaries, the sage man resigns to his ominous fate. Thus he resolves to respond their vile slanders with apathy towards the world by retiring himself to his own existence, and hence the effects of calumnies hurled at Rousseau by his enemies get weaker and eventually die out and pain him no more. Therefore Rousseau who had cut loose from the chains of conformity and alienated from each and every one reached the level of self-sufficiency. The centralization of «I» is the conception that Rousseau, as an exemplary model of the complexity of human being, provides the man with in order to help him keep the "balance between his passions and his faculties ... [and] to concentrate on the natural limits of being" (Eigeldinger, 1962, pp. 142-143).

Even though Rousseau of the Reveries claims to stop justifying himself to his contemporaries, he is restless and agitated to cajole them into the innocence of his intention through numerous examples; even though he tries to put on the act of apathy toward his enemies, he does not cease to denounce their hostility; even though he claims to have written his Reveries only for pleasure, he does not avoid playing his role as a theorist : the philosophical theory of the «golden age», the necessity of merging with nature, his perspective on the fleeting nature of earthly happiness, and the multidimensional aspect of falsehood that the author studied through a detailed examination impart his last book a theoretical dimension. These contradictions which mark deeply his Reveries have not yet led to a transparent identification of the standpoint of Rousseau. How should we disambiguate different trends of the great philosopher of the Romantic school? This is the question the reader of the Reveries has not figured out yet.

\section{References}

Bochet, M. (1997). Les Rêveries du promeneur solitaire de Rousseau. Paris : Hachette.

Bornecque, P. (1988). Les Rêveries du promeneur solitaire. Paris: Hatier.

Eigeldinger, M. (1962). Jean-Jacques Rousseau et la réalité de l'imaginaire. Neuchâtel: la Bacconière.

Lejeune, P. (1996). Le Pacte autobiographique. Paris: Seuil.

Perrin, J.-F. (2011). Politique du renonçant Le dernier Rousseau des Dialogues aux Rêveries. Paris: Kimé.

Rousseau, J.-J. (1965). Les Rêveries du promeneur solitaire suivi de Mon portrait Lettres à Malesherbes Notes écrites sur des cartes à jouer Introduction de Jean-Grenier Texte établi et annoté par S. De Sacy. Paris: Gallimard et Librairie Générale Française.

Rousseau, J.-J. (1966). Emile, ou de l'éducation Chronologie et Introduction par Michel Launay. Paris: GrenierFlammarion.

Rousseau, J.-J. (1967). Julie ou La Nouvelle Hélö̈se Chronologie et Introduction par Michel Launay. Paris: GrenierFlammarion.

Rousseau, J.-J. (1995). Les Confessions Présentation et notes Raymond Trousson. Paris: Imprimerie nationale.

Rousseau, J.-J. (1999). Dialogues Rousseau juge de Jean-Jacques suivis de Le Lévite d'Éphraïm Présentation, notes et dossier documentaire par Érik Leborgne. Paris: GF Flammarion.

Starobinski, J. (1999). L'oeil vivant Corneille, Racine, La Bruyère, Rousseau, Stendhal. Paris: Gallimard. 